\title{
Virginia H. Aksan, An Ottoman Statesman in War and Peace: Ahmed Resmi Efendi, 1700-1783 (Leiden, New York, 1995). Book Review by Maria Vaiou
}

Aksan's book, An Ottoman ${ }^{1}$ Statesman in War and Peace: Ahmed Resmi Efendi, 1700-1783 consists of four chapters. The first chapter describes Ahmed Resmi's early career. Based on historical chronicles and documentary evidence, Aksan argues that Ahmed Resmi Efendi ${ }^{2}$ was a member of the hacegân, the upper echelon of the chancery offices, and a typical representative of the kâtıb (secretaries) organisation in the eighteenth century. In this period, the Ottoman bureaucracy, and especially the offices involved with foreign affairs, namely the Chief Scribe/Foreign Affairs Officer, the Reisülküttab ${ }^{3}$ and his members, grew in size. Aksan points out that the factors leading to the growth of bureaucracy were the nature of scribal education, the importance of patronage and proficiency in imperial culture along with the professionalisation of foreign affairs and increased contact with Europe in this period. She stresses the role of the members of the chancery as diplomats and refers to the importance of the treaty of Karlowitz in $1699,{ }^{4}$ the terms of which were negotiated for the first time by a member of the bureaucracy.

Chapter two gives the context for the diplomatic exchanges in the eighteenth century and focuses on Ahmed Resmi's two embassies to Europe, in Vienna in 1757/58 and in Berlin in 1763/64. In the Ottoman empire, relations with other nations were carried out in the form of ad hoc diplomacy and successive sultans despatched envoys to foreign courts as necessity required. Diplomacy was non reciprocal in the sense of establishing permanent embassies abroad until the reforms of the sultan Selim III in the late eighteenth century (1789-1807). ${ }^{5}$ Ottoman foreign policy with Europe concentrated on alliance and mediation from 1740-1763. A consistent pattern of mediation was used in a number of Ottoman embassies despatched to European courts during treaty negotiations such as in Belgrade in 1739. Capitulations became permanent after 1740, and offers were made in 1745 to mediate in the War of Austrian Succession. ${ }^{6}$ Most ambassadors

\footnotetext{
${ }^{1}$ She defines the term 'Ottoman' as being a sincere Muslim, educated in Ottoman imperial culture, combining all branches of Islamic learning, blending the Arabic, Persian and Turkish languages, and dedicated to the perpetuation of religion and state as embodied in the sultan.

${ }^{2}$ On the title, see $E I^{2}$, 'Efendi', 2, 687.

${ }^{3} E I^{2}$, 'Re'îs ül-küttâb', 8, 481-3.

${ }^{4} E I^{2}$, 'farlofca', 4, 657-8; see R. A. Abou el-Haj, 'Ottoman Diplomacy at Karlowitz', in Ottoman Diplomacy: Conventional or Unconventional?, ed. A. Nuri Yurdusev (New York, 2004), 89-13.

${ }^{5}$ EI, 4, 219-222; Th. Naff, 'Reform and the conduct of Ottoman diplomacy in the reign of Selim III (1789-1807 ), JAOS vol. 83 (1963), 292-315; S. Shaw, Between old and new. The Ottoman empire under sultan Selim III, 1789-1807 (Cambridge, Mass., 1971).

${ }^{6}$ On the capitulations which developed as part of the amān system of Islam and as a continuation of the Byzantine tradition, see B. Ar1, 'Early Ottoman Diplomacy: Ad Hoc Period', in Ottoman
} 
came from the chancery elite and, being exposed to different systems, they challenged traditional assumptions. Their reports, which were included in the official histories of the period, not only describe the minutiae of the ceremonies of diplomacy and questions of protocol and precedence about which the Ottomans were precise when it concerned their diplomats, but allow glimpses into European powers. Only eight out of thirty-four reports do not deal with Europe. Similarly, Ahmed Resmi's reports of the two embassies he headed make his contribution to the genre of sefäretnāme (embassy reports) unique. ${ }^{7}$

Ahmed Resmi's embassy in Vienna aimed to announce the accession of Mustafa III (1757-74) ${ }^{8}$ as sultan, according to tradition. Diplomatic protocol demanded that Ahmed Resmi had an interview with the sultan Mustafa III prior to his departure for Vienna; the latter presented him with his official letter credentials. Gifts were the most essential part of embassies: a ceremony for the inspection and transfer of gifts which were to accompany the ambassador took place before his departure. ${ }^{9}$ Ahmed Resmi reportedly had an entourage of more than sixty people. Resmi, in his reports of the embassy, describes the details of the voyage to and from Vienna, and their stay which lasted three months, his presentation of letters to Maria Teresa (1740-80) and her husband Francis (1745-1765), and the state of affairs in Austria and between Austria and Prussia. The reports exhibit simplicity

Diplomacy: Conventional or Unconventional?, 41-3. For the capitulations intended to stimulate trade with the West and regulate the presence of foreign merchants in the Ottoman domains, see EI2, 'Imtiyāzāt', vol. 3, 1178-89; M. H. Van den Boogert, The Capitulations and the Ottoman Legal System: Qadis, Consults and Beraths in the 18th century (Leiden, Boston, 2005), 7; Th. Naff, 'Ottoman diplomatic relations with Europe in the eighteenth century: patterns and trends', in Studies in Eighteenth Century Islamic History, ed. Th. Naff and R. Owen (Carbondale, 1977), 88-107.

${ }^{7}$ See also Abdlülkerim Efendi's sefaretname for his embassy to Moscow in 1775, in N. Itzkowitz and M. E. Mote, Mubadele - an Ottoman - Russian exchange of ambassadors, tr. N. Itzkowitz (Chicago, London, 1970), 10-4, 55-120 which shares many similarities with Resmi's; on sefāret-nāmes as sources of Ottoman diplomacy, see Ottoman Diplomacy: Conventional or Unconventional?, 175-9; see also J. M. Stein, 'Habsburg financial institutions presented as a model for the Ottoman empire in the sefaretname of Ebu Bekir Ratib Efendi', in Habsburgisch-osmanische Beziehungen, Colloque sous le patronage du Comité international des études pré-ottomanes et ottomanes Herausgegeben von Andreas Tietze (Wien, 1985), 233-241.

${ }^{8} E I^{2}, 7,708-9$; for an interesting survey of Ottoman embassies sent to Vienna and a list of Ottoman envoys in the period between 1797-1919, see R. H. Davison, 'Vienna as a major Ottoman diplomatic post in the nineteenth century', in Habsburgisch-osmanische Beziehungen, 251-280 at 273-4. He fails though to mention Ahmed Resmi's embassy.

9 The protocol of the ambassador's reception of the royal letter and his possession of gifts is also observed in 1775 for the embassy of Abdlülkerim Efendi before he set out on his mission; see Mubadele - an Ottoman - Russian exchange of ambassadors, 16-22; on diplomatic protocol at the Ottoman court, see Ottoman Diplomacy: Conventional or Unconventional?, 46, 50; on an account of gifts to Ottoman court by a German embassy in 1578-8, see H. Reindl-Kiel, 'East is East and West is West, and Sometimes the Twain Did meet Diplomatic Gift Exchange in the Ottoman Empire', in Frontiers of Ottoman Studies; State, Province, and the West, ed. C. Imber, K. Kiyotaki \&R. Murphey (London, 2005), 113-23; For similar practices used between the Byzantines and Muslims, see Diplomacy in the early Islamic World. A tenth century treatise on Byzantine-Arab relations, tran. M. Vaiou (London, 2008), forthcoming. 
of style, an objective observation of the 'other', and an intelligent discussion of the historical circumstances in relation to Prussia's king Frederick the Great and Austria. Vâsif Efendi, the official chronicler of the latter half of the eighteenth century, recommends they be read by all as they were "pleasing and free of nonsense, and among the rare works of the pen offered to the sultan'. Resmi's knowledge of Austria and Prussia were no doubt factors in his selection for the next embassy to Berlin in 1763.

Aksan discusses the background to the despatch of Ahmed Resmi's embassy to Berlin and stresses that the aim was an Ottoman-Prussian alliance. The preparation for the embassy resembled that of Vienna. Two ceremonies preceded his departure: one was for the transference of letters and gifts and a second for the farewell interview with the sultan. In this report of the embassy to Berlin, Resmi gives extensive descriptions of a number of places en route to Berlin and a positive analysis of Frederick the Great and his policies; he was impressed by the king's leadership qualities, and education; he provides a useful account of European society and morals. ${ }^{10}$ Ahmed Resmi's transmission of such information was unique for this period's Ottoman writing and may have influenced the circle of advisors which later developed around Sultan Selim III.

According to Resmi's reports, ten days after his arrival in Berlin, he met the chief minister to submit the Grand Vizier's letter and establish the protocol for the reception by King Frederick. Following this, the preparations for submission of the sultan's gifts began; they were sent to the palace a day before the official reception by members of the embassy and an interpreter, and were set up in a corner of the reception hall on Persian carpets. The procession to the palace, led by the escort who was provided by the king, consisted of the ambassadorial retinue riding on horses. Arriving at the palace, the ambassador and fifteen of the retinue moved into the reception hall with the sultan's letter in the hands of the embassy secretary and the sultan's crest in the hands of the chamberlain (kethüda). Resmi gives a very vivid description of the etiquette followed during the reception, which was in fact, the first reception of an Ottoman ambassador received by Prussia: there it is said that Resmi conveyed his official message from the sultan concerning the letter of friendship and gifts. "Thereafter, the letter and the crest were placed in the king's hands one by one. He [Frederick] measured the value of the crest out of his eyes and placed it on the table next to him. Then, through an interpreter, the king welcomed the ambassador and thanked him for the good wishes of his master.' Resmi describes an interview he had with the king several days later following another reception, providing details of one of his conversations with Frederick, and refers to the king's reply to the official letter of Mustafa III, six months after the arrival of the embassy. Resmi's embassy had no political

\footnotetext{
${ }^{10}$ For background discussion, see Aksan, An Ottoman Statesman in War and Peace Ahmed Resmi Efendi, 1700-1783, 64ff.

${ }^{11}$ For similar examples of Ottoman envoys to foreign courts, see Ottoman Diplomacy: Conventional or Unconventional?, 52-6.
} 
significance and his impact lay in the reports he left contributing to the Ottoman perception of the Prussian state system. ${ }^{12}$ In 1764, after his return from Berlin, Resmi was appointed Chief Correspondence Officer to the Grand Vizier (Mektupçu) thus gaining access to the upper echelon of administration.

Chapter three examines the Russo-Turkish war (1768 to 1774) and Ahmed Resmi's role as plenipotentiary to the peace negotiations which ended it. The signing of the treaty of Küçük Kaynarca ${ }^{13}$ in 1774 that was humiliating for the Ottomans and famous for establishing the Russians as a major force in Balkan and Middle Eastern affairs lay in the hands of Ahmed Resmi. Thus, between 1775 and shortly before his death in 1783, he was cast into disgrace, disappearing from the chronicles and official appointment rolls. In his Layiha, (memoirs) written on the battlefront after 1769, Resmi focuses on the issues of the breakdown of the Ottoman military system and proposes a series of reforms. His analysis of the problems facing the administration represent a break with 'sultan-centred cycles of virtue and justice' towards '..... more profound social critique...' In a second treatise, written in 1772, Resmi, influenced by Ibn Khaldûn and drawing on examples from the Koran, stresses the benefits of peace instead of war, defined borders, and maintenance of power through diplomacy and negotiation which were, until then, novel notions in the light of Ottoman ideas of permanent expansion. The same themes are addressed in his Hulâsat, composed circa 1780, drawing on verses from the Koran and historical examples. Ahmed Resmi, along with Sadullah Enverî and Ahmed Vâsif, left the fullest descriptions of the 1768-1774 war and its aftermath.

Chapter four examines Ahmed Resmi's post-war career and contribution to Ottoman political discourse. Resmi was an influence in the signing of the 1779 Aynalıkavak agreement over the question of the Russian occupation and annexation of the Crimea, and a member of numerous councils. Aksan argues that Resmi, as reflected in his writings, was convinced about the merits of joining the European state system and called for a transformation of Ottoman society and a change of the Janissary corps. Under Selim III, the urgency of military reform was evident and further works such as those of Ebubekir Ratib Efendi, who was ambassador to Vienna in 1791-2, and Tatarcck Abdullah Efendi, a military judge, are part of the response to the process of the 1768 to 1774 war and the critical observations of Resmi.

Aksan's book is a contribution to the field of Ottoman diplomacy in terms of the novel discussion she provides on Ottoman diplomatic practices and Ahmed Resmi's career as a diplomat and statesman in the eighteenth century empire. Her accounts on Resmi's embassies must be read in corroboration with other such accounts to trace evidence of continuity of diplomacy and give us a better understanding of the larger history of the relations between the two states.

\footnotetext{
${ }^{12}$ See V. Aksan, 'An Ottoman Portrait of Frederick the Great', Turkish Studies Association Bulletin vol. 16, no 2 (1992); on Resmi's sefāret-nāme, see Ottoman Diplomacy, 177 n. 40, 189, n. 30.

${ }^{13} E I^{2}, 5,312-3$.
} 